\title{
Bacterial Crown Gall of Roses Caused by Agrobacterium tumefaciens ${ }^{1}$
}

\author{
Kamil Duman, Susannah da Silva, Fanny Iriarte, Barron Riddle, Gary Knox, Matthew Orwat, \\ Shawn Steed, E. Vanessa Campoverde, Jeffrey Jones, and Mathews Paret ${ }^{2}$
}

\section{Introduction}

Crown gall is a bacterial disease that causes large, tumorlike swellings (galls) that often occur at the crown of the plant, just above the soil line (Figure 1), resulting in plant disfigurement and eventually plant death. The pathogen Agrobacterium tumefaciens infects hundreds of plant species including roses. It also survives in soil for up to three years, which greatly affects disease management practices.

\section{Symptoms}

Galls result from uncontrolled growth of undifferentiated host plant tissue at the infection site of Agrobacterium tumefaciens. Infection only occurs through wounds; these can result from horticultural practices such as pruning, or from environmental damage such as freezing. Infection of rose commonly occurs at the soil line (crown) (Figures 1 and 6), but can also occur on branches or roots (Figure 2, 3, $4,5)$.

Galls are initially light in color (Figure 2), but over time the outer plant cells die and the galls darken (Figures 3, 5, and 6). Sometimes galls are indistinguishable from normal plant tissue due to pruning scars or other environmental factors leading to gall-like appearance. The bacteria can invade wounds (injuries) on the branches or roots (Figures 3 and 4). Swelling or gall formation can be seen as early as 14 days or as late as 6 months following the entry of the bacterium into the plant. The tissue near the gall suffers a rapid cell proliferation. If vascular tissue is affected, wilting can result from the restricted water movement. However, this is not a common symptom.

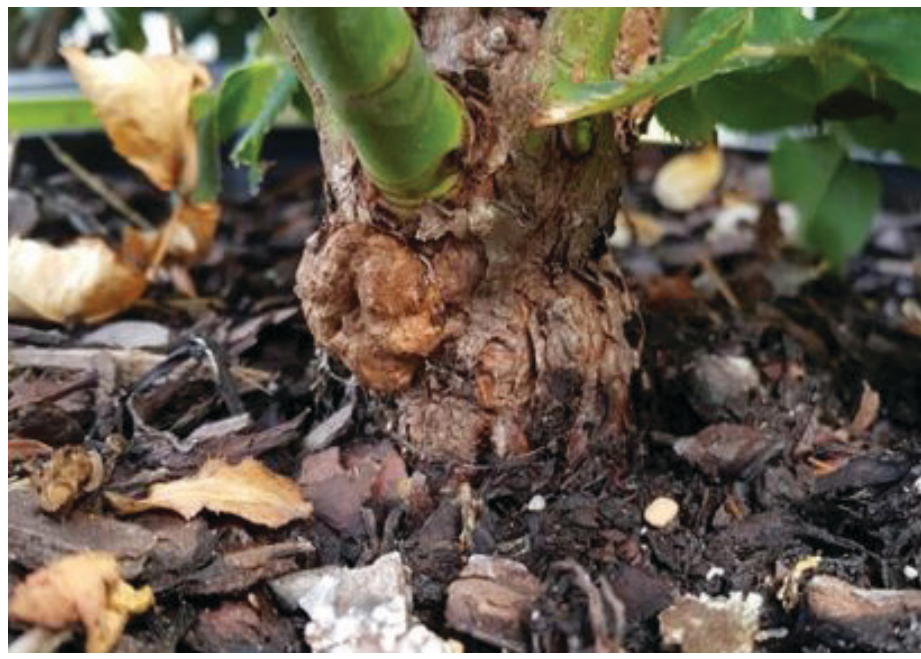

Figure 1. Later stage crown gall symptoms at the base of a rose plant caused by the bacterium Agrobacterium tumefaciens.

Credits: Kamil Duman, UF/IFAS

1. This document is PP343, one of a series of the Plant Pathology Department, UF/IFAS Extension. Original publication date November 2018. Visit the EDIS website at https://edis.ifas.ufl.edu for the currently supported version of this publication.

2. Kamil Duman, visiting scientist, UF/IFAS North Florida Research and Education Center (NFREC); Susannah da Silva, planty pathology agricultural/ food scientist II, UF/IFAS NFREC; Fanny Iriarte, plant disease diagnostician, UF/IFAS NFREC; Barron Riddle Sr., biological scientist, UF/IFAS NFREC; Gary Knox, professor, Environmental Horticulture, UF/IFAS NFREC; Matthew Orwat, Extension agent, UF/IFAS Extension Washington County; Shawn Steed, Extension agent, UF/IFAS Extension Hillsborough County; E. Vanessa Campoverde, Extension agent, UF/IFAS Extension Miami-Dade County; Jeffrey Jones, professor, Bacteriology, Plant Pathology Department; and Mathews Paret, associate professor, Plant Pathology Department, UF/IFAS NFREC; UF/ IFAS Extension, Gainesville, FL 32611.

The Institute of Food and Agricultural Sciences (IFAS) is an Equal Opportunity Institution authorized to provide research, educational information and other services only to individuals and institutions that function with non-discrimination with respect to race, creed, color, religion, age, disability, sex, sexual orientation, marital status, national origin, political opinions or affiliations. For more information on obtaining other UF/IFAS Extension publications, contact your county's UF/IFAS Extension office. 


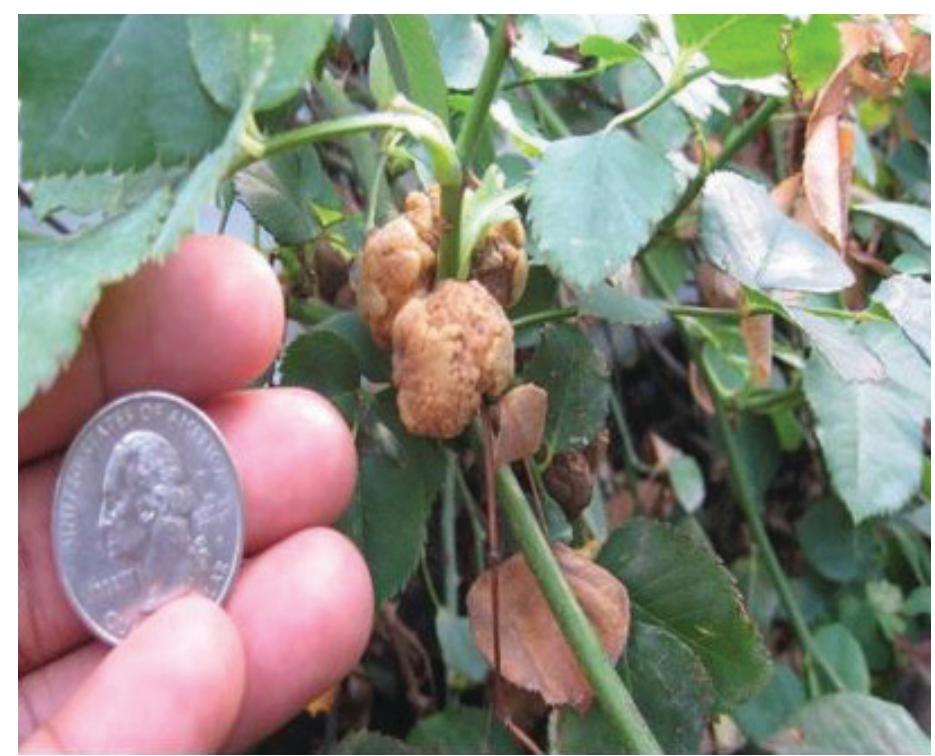

Figure 2. Galls can appear on roses infected with A. tumefaciens within 2-3 weeks.

Credits: Mathews Paret, UF/IFAS

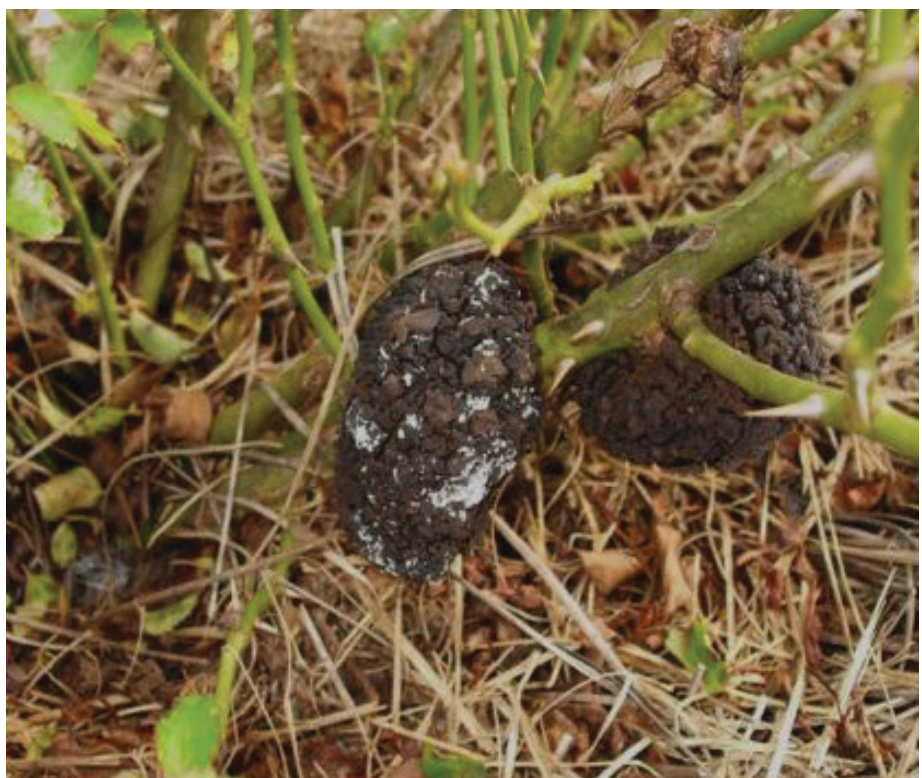

Figure 3. Galls on roses turn dark in color as they age.

Credits: Kamil Duman, UF/IFAS

\section{Pathogen: Biology and Spread}

The crown gall bacterium, Agrobacterium tumefaciens, is a soilborne bacterium. It can enter the plant from the soil through wounds on the roots, lower stems, or from the branches during plant pruning. Symptoms are caused by the insertion of a small segment of transfer-DNA (T-DNA) from its plasmid into the host plant cell, which is incorporated into the plant genome. Once the T-DNA integrates into the plant chromosome, the altered plant cells start dividing rapidly and uncontrollably, and the infected tissue develops a tumor-like swelling. Galls can range from pea size to softball size. Tiny cracks from freezing temperatures or wound sites can be the sites for gall formation.
One of the common ways the disease spreads is by pruning healthy plants with the same non-sanitized pruning tool used on an infected plant, causing galls to form at the pruning site (Figure 5). Also, following pruning, gall tissue from infected plants can land in the soil and the pathogen can persist for several years (Figure 6). The bacterium can spread easily during field preparation, pruning, and irrigation. Insects, nematodes, and grafting materials can also transfer the bacterium. However, from an agricultural standpoint, the bacterium is found mostly on pome and stone fruit trees, roses, raspberries, blackberries, and grapes. We currently do not know whether the strains isolated from Florida and Georgia roses infect other plant species.

The crown gall disease cycle highlights how this pathogenic bacterium is disseminated and infects roses (Figure 7).

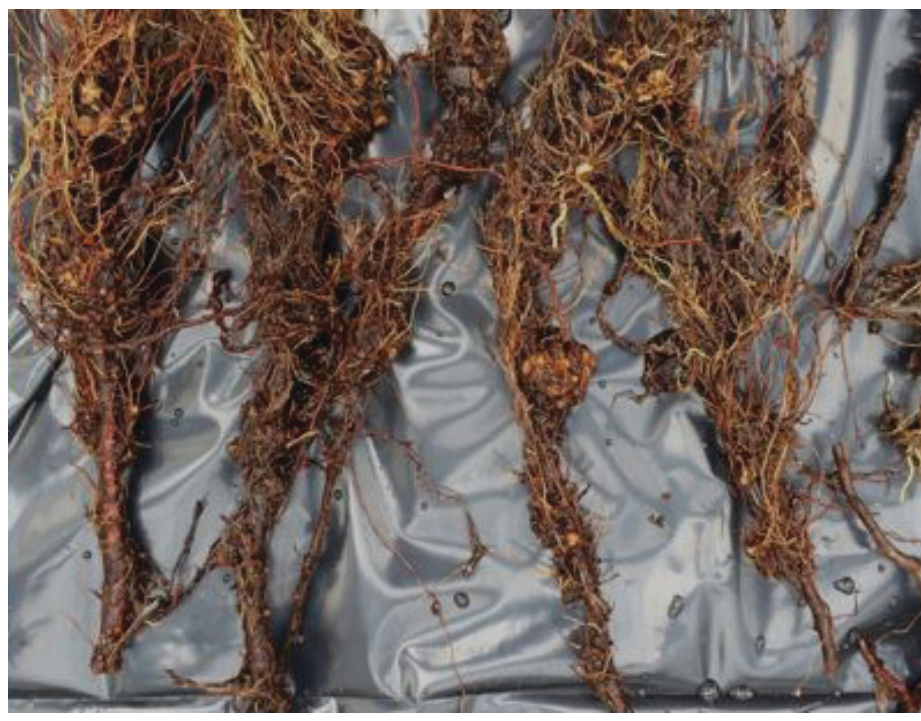

Figure 4. Galls on primary and secondary roots of roses. Credits: Susannah da Silva, UF/IFAS

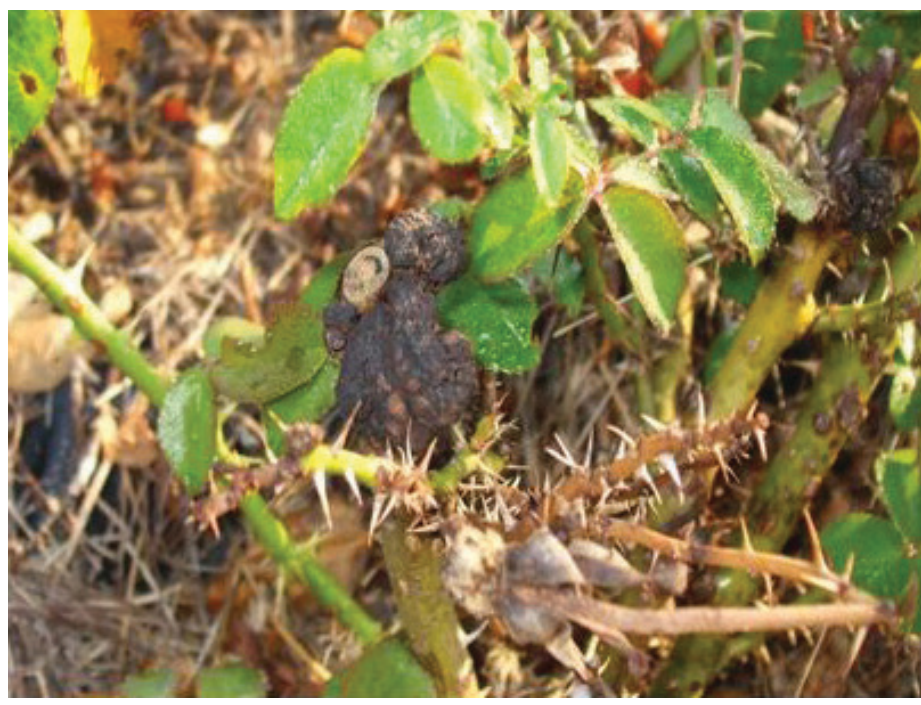

Figure 5. Gall formation at pruning sites indicates inoculation of the plant during pruning.

Credits: Kamil Duman, UF/IFAS 


\section{Disease Management}

- Plant only pathogen-free roses. When you receive new plant material, check very carefully for galls on the crown, branches, and roots.

- Plant in clean soil (avoid locations with a history of crown gall infestation for at least three years).

- Avoid locations with heavy infestations of root-attacking insects and nematodes.

- Select well-drained soil and irrigate from clean water sources (i.e., water that is treated, or is not known to have contact with this pathogen).

- Disinfect pruning tools between plants and budding/ grafting tools before and after use. Bleach (10\%; equivalent to $0.6 \%$ sodium hypochlorite) or quaternary ammonium-based sanitizers are effective disinfectants. Make sure to prepare fresh stock regularly.
- Keep grafts and buds well above the soil line.

- Rogue infected plants, as the likelihood of accidental transmission to healthy plants is high. Destroy infected plants through burning to prevent further contamination.

- Avoid mechanical injury to plants from pruning and tillage.

- Provide winter protection to rose plants to avoid damage to bark.

- While there are biological control strains and chemical compounds available for crown gall management, their efficacy on roses is not known.

- If crown gall plants are noted, please contact your local UF/IFAS Extension agent for information on management.

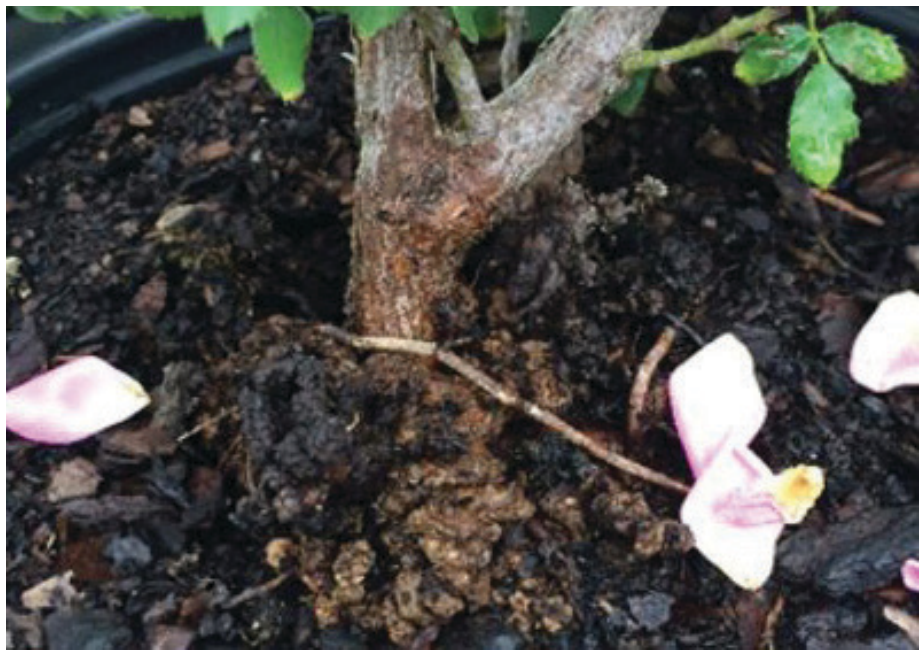

Figure 6. A plant with a mature gall in contact with the potting soil. Credits: Susannah da Silva, UF/IFAS

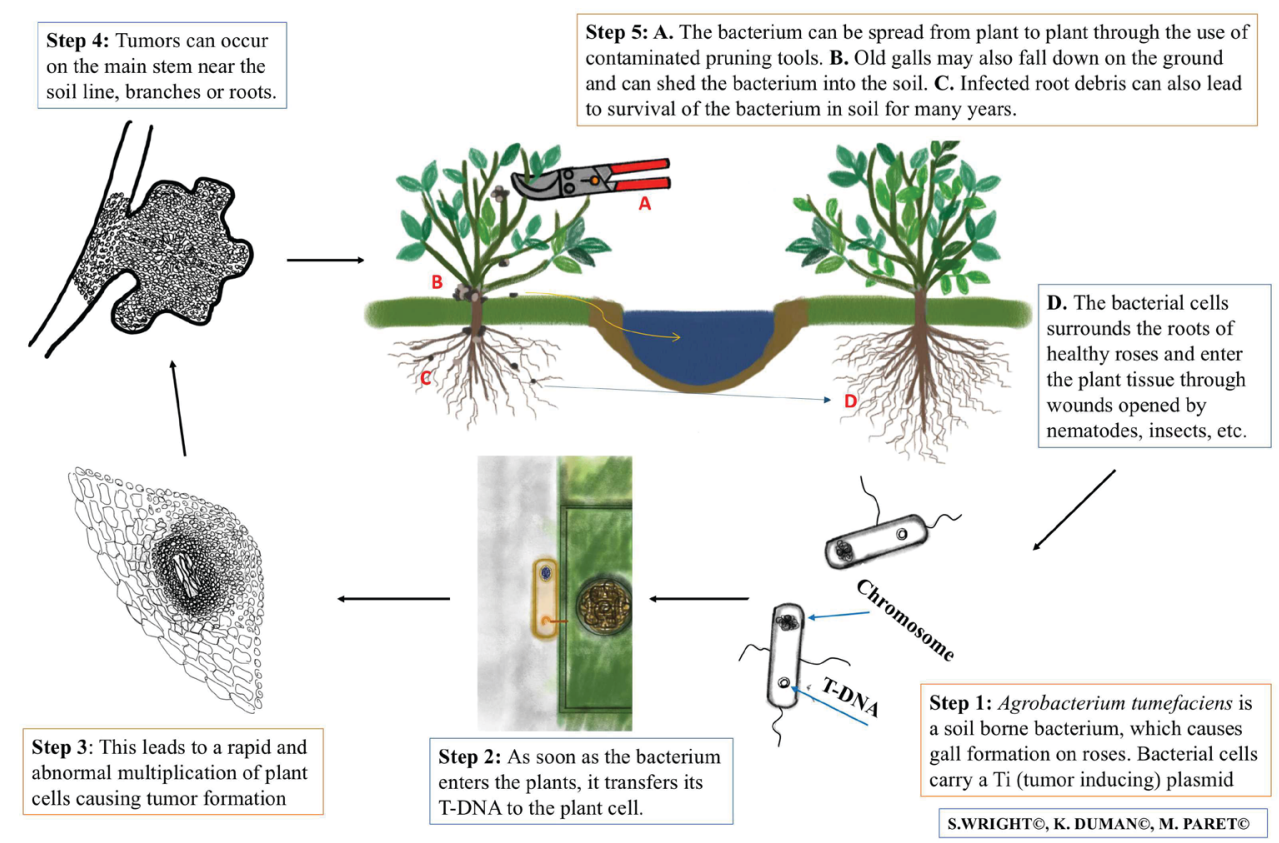

Figure 7. A summary of the disease cycle of crown gall, caused by Agrobacterium tumefaciens.

Credits: Kamil Duman, Susannah da Silva, and Mathews Paret, UF/IFAS 